\title{
Study of implications of thyroid status over feto-maternal outcomes in pregnancy
}

\author{
Smruti Gedam, Bharat Bhushan*
}

Department of Obstetrics and Gynecology, Government Medical College and Hospital, Nagpur, Maharashtra, India

Received: 08 February 2020

Accepted: 03 March 2020

\section{*Correspondence:}

Dr. Bharat Bhushan,

E-mail: drbharatbhushanobgy@ rediffmail.com

Copyright: (C) the author(s), publisher and licensee Medip Academy. This is an open-access article distributed under the terms of the Creative Commons Attribution Non-Commercial License, which permits unrestricted non-commercial use, distribution, and reproduction in any medium, provided the original work is properly cited.

\begin{abstract}
Background: Thyroid disorders are reported at clinically significant prevalence during pregnancy, affecting $\sim 5 \%$ of all pregnancies. Maternal thyroid status during pregnancy purportedly affects fetal as well as maternal outcomes. The objective of present study was to analyse the relationship of thyroid status in pregnancy and various maternal and fetal outcomes.

Methods: In this hospital based observational study, a total of 913 pregnant women were enrolled as per fixed criteria and all the study participants were screened for thyroid disorders. Further, they were followed up throughout pregnancy and puerperium and evaluated for various maternal and fetal complications by predefined outcome measures. The results were compared by subgroup analysis.

Results: Of the 913 patients screened, 105 were diagnosed with thyroid abnormality and followed up till delivery, with newborn thyroid profile on day 7 . Total 49 patients were diagnosed with anaemia $(46.66 \%)$, of which 46 $(43.80 \%)$ had subclinical hypothyroidism ( $\mathrm{p}<0.05)$; along with pregnancy induced hypertension in $42(40 \%)$ cases of which $40(38.09 \%)$ had subclinical hypothyroidism were observed to have statistically significant associations. Intrauterine growth restriction (IUGR) $(37,35.23 \%)$ and prematurity $(19,18.1 \%)$ were the most common fetal occurrences; the association of IUGR and subclinical hypothyroidism being statically significant.

Conclusions: Thyroid disorders during pregnancy are commonly associated with maternal and fetal complications and thyroid profile is recommended as universal screening method in early pregnancy to diagnose and start required treatment early.
\end{abstract}

Keywords: Fetal complication, Maternal complication, Pregnancy, Thyroid status

\section{INTRODUCTION}

Thyroid hormone status is one parameter which affects almost every organ/system in the body. Thyroid disease is being increasingly diagnosed with greater awareness and, incidentally, affects females more. The global goiter prevalence is $>2$ billion with around 40 million in India, making the country one of the worst affected. ${ }^{1}$ Thyroid dysfunction also has, unfortunately, relatively high prevalence during pregnancy, affecting up to $5 \%$ of all pregnant women; with maternal hypothyroidism being most frequent. ${ }^{2}$
Maternal thyroid disorders may influence multitude of mother and fetal outcomes. ${ }^{3}$ There is imperative need to treat thyroid disorders in reproductive age women before conception. In pregnancy, overt hypothyroidism is seen in $0.2 \%$ and subclinical hypothyroidism in $2.3 \%$ cases; and even subclinical hypothyroidism has been observed to affect perinatal outcomes significantly. ${ }^{4}$ Anemia, preeclampsia, prematurity, fetal loss and fetal growth restriction, low birth weight and neonatal hyperbilirubinemia are the usually reported complications of thyroid dysfunction. ${ }^{5-7}$ 
Only few Indian studies have dwelled into the effect of thyroid status over various complications during maternal/perinatal period. With the prevailing research gap in mind, the present study was planned with the objective of analysis the relationship of maternal thyroid status in pregnancy and various maternal and fetal outcomes.

\section{METHODS}

This was a hospital based observational study, conducted in the department of obstetrics and gynecology at a tertiary care teaching hospital over a period of one year (March 2018 to February 2019).

All pregnant women visiting the hospital for obstetric care constituted the study population. Those patients fulfilling the following selection criteria were considered for the study.

\section{Inclusion criteria}

- $\quad$ Age between 18-45 years

- Pregnant women with diagnosed thyroid abnormality

- Continued participation in all three trimesters.

\section{Exclusion criteria}

- Diagnosed cases of diabetes mellitus and/or hypertension

- Refusal to provide consent.

Necessary approval was obtained from the Institutional Ethics Committee before initiation of the study and all the participants were explained in detail about the study protocol before consent for participation was sought. All the patients screened through above criteria were subjected to detailed history taking and physical examination at the time of recruitment of the study. A comprehensive obstetric examination was then undertaken. This was followed by assessment of serum thyroid profile, among other hematological parameters as warranted by the clinical condition. The patients were followed up throughout antenatal and perinatal period and the outcome of each patient was measured and documented with standard parameters keeping in mind the generalizability of the study findings. Subgroup analysis was conducted by classifying the patients as per their thyroid hormone status into four categories: 'overt hyperthyroidism', 'overt hypothyroidism', 'subclinical hyperthyroidism' and 'subclinical hypothyroidism'.

\section{Statistical analysis}

The data was analysed using SPSS (version 20) by applying chi-square test. The level of significance was arbitrated at $\mathrm{p}<0.05$.

\section{RESULTS}

A total of 913 pregnant women were screened for thyroid status after applying various inclusion and exclusion criteria. Of the 913 patients, 105 were diagnosed as having thyroid abnormalities $(11.5 \%)$ and were followed up till delivery, with thyroid profile of new-born done on day 7. Of the 105 participants having thyroid abnormalities; 88 patients had subclinical hypothyroidism $(83.8 \%)$, followed by overt hypothyroidism in 14 patients (13.3\%) (Table 1).

Table 1: Incidence of thyroid disorders in pregnancy.

\begin{tabular}{|l|ll|}
\hline Thyroid disorder & Number & Percentage \\
\hline Sub clinical hypothyroidism & 88 & $83.8 \%$ \\
\hline Overt hypothyroidism & 14 & $13.3 \%$ \\
\hline Sub clinical hyperthyroidism & 1 & $1.0 \%$ \\
\hline Overt hyperthyroidism & 2 & $1.9 \%$ \\
\hline Total & 105 & $100 \%$ \\
\hline
\end{tabular}

Table 2: Incidence of maternal complications and relationship with thyroid status during pregnancy.

\begin{tabular}{|c|c|c|c|c|c|c|}
\hline Thyroid status & Total & $\begin{array}{l}\text { Overt } \\
\text { hyper- } \\
\text { thyroidism }\end{array}$ & $\begin{array}{l}\text { Overt } \\
\text { hypo- } \\
\text { thyroidism }\end{array}$ & $\begin{array}{l}\text { Subclinical } \\
\text { hyper- } \\
\text { thyroidism }\end{array}$ & $\begin{array}{l}\text { Subclinical } \\
\text { hypo- } \\
\text { thyroidism }\end{array}$ & p value \\
\hline Maternal complication & $\mathbf{N}(\%)$ & $\mathbf{N}(\%)$ & $\mathbf{N}(\%)$ & $\mathbf{N}(\%)$ & $\mathbf{N}(\%)$ & \\
\hline Anaemia & $49(46.66 \%)$ & 0 & $3(2.85 \%)$ & 0 & $46(43.80 \%)$ & $<0.05$ \\
\hline Pregnancy induced hypertension & $42(40 \%)$ & 0 & $2(1.90 \%)$ & 0 & $40(38.09 \%)$ & $<0.05$ \\
\hline Gestational diabetes mellitus & $08(7.61 \%)$ & 0 & $2(1.90 \%)$ & 0 & $6(5.71 \%)$ & $>0.05$ \\
\hline Oligohydramnios & $09(8.57 \%)$ & 0 & $1(0.95 \%)$ & 0 & $8(7.61 \%)$ & $>0.05$ \\
\hline Preterm labour & $06(5.71 \%)$ & $1(0.95)$ & $2(1.90 \%)$ & 0 & $3(2.85 \%)$ & $>0.05$ \\
\hline Preterm PROM & $02(1.90 \%)$ & 0 & 0 & 0 & $2(1.90 \%)$ & - \\
\hline Term PROM & $04(3.80 \%)$ & 0 & 0 & 0 & $4(3.80 \%)$ & - \\
\hline Abruptio placentae & $02(1.90 \%)$ & 0 & 0 & 0 & $2(1.90 \%)$ & - \\
\hline Post-partum hemorrhage & $08(7.61 \%)$ & 0 & 0 & 0 & $8(7.61 \%)$ & $<0.05$ \\
\hline Wound infection & $10(9.52 \%)$ & 0 & 0 & 0 & $10(9.52 \%)$ & $<0.05$ \\
\hline
\end{tabular}


Of the 105 cases, $71(67.6 \%)$ were newly diagnosed and $34(32.4 \%)$ were already diagnosed with thyroid abnormality and were on medication. Most were in the age group of 26-30 years $(55,52.4 \%)$, followed by $21-25$ years $(25,23.8 \%)$ and $30-35$ years $(20,19.1 \%)$; amongst others. Of the total 105, $62(59.9 \%)$ participants were primigravida and $43(40.1 \%)$ were multigravida.

Study of various maternal complications showed 49 patients to be diagnosed with anaemia (46.66\%), of which total $46(43.80 \%)$ had subclinical hypothyroidism ( $\mathrm{p}<0.05)$. Pregnancy induced hypertension was observed in $42(40 \%)$ cases of which total $40(38.09 \%)$ cases had subclinical hypothyroidism ( $\mathrm{p}<0.05)$; both the associations being statistically significant. Wound infection was noted in $10(9.52 \%)$ patients and all of them had subclinical hypothyroidism $(\mathrm{p}<0.05)$. Postpartum hemorrhage occurred in $8(7.61 \%)$ cases, all of which were sub-clinically hypothyroid, the association being statistically significant (Table 2). A total of 90 out of $105(85.71 \%)$ babies were born alive. Study of association of fetal complications revealed intrauterine growth restriction (IUGR) $(37,35.23 \%)$ and prematurity $(19,18.1 \%)$ to be the commonest occurrences; the association of IUGR and subclinical hypothyroidism being statically significant (Table 3 ).

Out of 105 cases, 9 patients had abortions, 29 (30.20\%) patients had full term normal vaginal delivery, 15 $(15.62 \%)$ patients had preterm delivery (of which 4 were anomalous babies terminated in early gestation) and 52 $(54.16 \%)$ were LSCS. Twenty seven out of 29 cases of vaginal deliveries and 44 out of total 52 cases of LSCS were subclinical hypothyroid. In neonatal complications, hyperbilirubinemia was observed in 49 (51.04\%) babies, out of which $44(45.83 \%)$ babies were of mother with subclinical hypothyroid ( $\mathrm{p}<0.05$ ); followed by low birth weight babies $(55,57.29 \%)$, out of which $48(50 \%)$ babies were of mother with subclinical hypothyroid, also statistically significant ( $\mathrm{p}<0.05)$. Neonatal TSH on day 7 in the 90 babies born alive was normal in 89 (98.89\%) babies with $1(1.11 \%)$ baby having congenital hypothyroidism.

Table 3: Incidence of fetal complications and relationship with thyroid status during pregnancy.

\begin{tabular}{|c|c|c|c|c|c|c|}
\hline Thyroid status & Total & \multirow{2}{*}{$\begin{array}{l}\text { Overt } \\
\text { hyper- } \\
\text { thyroidism }\end{array}$} & \multirow{2}{*}{$\begin{array}{l}\text { Overt hypo- } \\
\text { thyroidism }\end{array}$} & \multirow{2}{*}{$\begin{array}{l}\text { Subclinical } \\
\text { hyper- } \\
\text { thyroidism }\end{array}$} & \multirow{2}{*}{$\begin{array}{l}\text { Subclinical } \\
\text { hypo- } \\
\text { thyroidism }\end{array}$} & \multirow{2}{*}{ p value } \\
\hline Fetal complication & $\mathbf{N}(\%)$ & & & & & \\
\hline Abortion & $09(8.57 \%)$ & $1(0.95 \%)$ & $2(1.90 \%)$ & 0 & $6(5.71 \%)$ & $>0.05$ \\
\hline Intrauterine fetal demise & $02(1.90 \%)$ & 0 & 0 & 0 & $2(1.90 \%)$ & $>0.05$ \\
\hline Anomalous baby & $04(3.80 \%)$ & 0 & $2(1.90 \%)$ & 0 & $2(1.90 \%)$ & $>0.05$ \\
\hline Intrauterine growth restriction & $37(35.23 \%)$ & 0 & $2(1.90 \%)$ & 0 & $35(33.33 \%)$ & $<0.05$ \\
\hline Prematurity & $19(18.09 \%)$ & $1(0.95 \%)$ & $4(3.80 \%)$ & 0 & $14(13.33 \%)$ & $>0.05$ \\
\hline
\end{tabular}

\section{DISCUSSION}

The present study was undertaken to understand the effect of maternal thyroid status and implications of its derangement over various maternal and fetal outcomes. The number of people with thyroid disorder was 105 $(11.5 \%)$, with majority of them $(88,83.8 \%)$ having subclinical hypothyroidism, followed by overt hypothyroid $(14,13.3 \%)$. Maternal thyroid status has been observed to vary across studies. In the study by Saraladevi $\mathrm{R}$ et al, the prevalence of subclinical hypothyroid was $59.3 \%$, subclinical hyperthyroid was $66.7 \%$, overt hypothyroid was $40.7 \%$ and overt hyperthyroid was $35.3 \% .^{8}$ Ajmani et al, reported prevalence of subclinical hypothyroid at $24.5 \%$, overt hypothyroid $27.1 \%$, subclinical hyperthyroid $26 \%$ and overt hyperthyroid as 30\%. ${ }^{9}$ Whereas studies by Meena DS et al and Nazarpour $\mathrm{S}$ et al had hypothyroid prevalence reported at $95 \%$ and $97.3 \%$ respectively. ${ }^{10,11}$ The age distribution of present study participants was similar to previous studies. Present study had, out of total 105 participants, $62(59.04 \%)$ primigravida and 43 $(40.96 \%)$ multigravida; of which 61 (58.09\%) were hypothyroid primigravida and 41 (39.04\%) were hypothyroid multigravida. This proportion varied in different studies. In study of Meena DS et al, primigravida were $32 \%$ and multigravida were $68 \% .{ }^{10} \mathrm{In}$ study of Saraladevi et al, primigravida hypothyroid were $40.07 \%$ and multigravida hypothyroid were $39.3 \% .^{8}$ In the present study, the total cases of infertility were 29 $(27.61 \%)$, out of which primary infertility were 24 cases $(22.85 \%)$ and secondary infertility were 5 cases $(4.7 \%)$ in numbers; all of them suffering from hypothyroidism. No cases of infertility were seen in hyperthyroid cases. While in the study by Meena DS et al, 34\% cases of infertility were hypothyroid and $2 \%$ cases were of hyperthyroidism. ${ }^{10}$

In the present study, anaemia was noted in $49(46.66 \%)$ out of 105 cases of thyroid disorders and PIH was noted in $42(40 \%)$ cases; which is comparable with study of Meena DS et al, in which $60 \%$ patients had anaemia and $30 \%$ patients had PIH amongst 100 patients of thyroid disorder studied by them. In the study by Ajmani et al, out of 53 cases of thyroid disorder, 10 (18.86\%) had PIH and $6(11.32 \%)$ had anaemia. ${ }^{9}$ GDM and PPH incidences 
were also comparable across all studies, accounting for an average of $7-8 \%$ and $5-10 \%$ cases respectively. ${ }^{8,10,11}$ The incidences of all the mentioned associated maternal complications were higher in those with deranged thyroid status than in normal population, which is largely corroborative of available evidence.

In present study, 37 (38.54\%) fetuses were IUGR, 55 $(57.29 \%)$ babies were low birth weight and 19 (19.79\%) of babies were preterm. While in other studies, low birth weight and preterm babies were the significant occurrences; accounting for $24.52 \%$ and $26.41 \%$ cases respectively in the study by Meena DS et al, and $45.45 \%$, $39.39 \%$ cases respectively in the study by Ajmani et al. ${ }^{9,10}$ The statically significant association between IUGR and subclinical hypothyroidism observed in the present study was also observed by most of the previous researchers. ${ }^{9-12}$

Present study had total 52 cases of cesarean sections, of which $14(26.92 \%)$ cases of section were for nonprogress of labour, $14(26.92 \%)$ for fetal distress, 12 $(23.07 \%)$ cases due to IUGR and $06(11.53 \%)$ cases due to CPD. While in study of Meena DS et al, out of 61 cases of section, $11(18.03 \%)$ were due to non-progress of labour, $5(8.19 \%)$ due to fetal distress and $13(21.31 \%)$ due to IUGR. ${ }^{10}$ Twenty seven out of 29 cases of vaginal deliveries were subclinical hypothyroid and 44 out of total 52 cases of LSCS were subclinical hypothyroid, which is in line with the proportion Nazarpour S et al had observed, amongst others. ${ }^{8-10}$

In the present study, there were $3(3.12 \%)$ babies with birth weight $<1.5 \mathrm{~kg}$ (all were born anomalous), 21 (21.87\%) between 1.6-2 kg, $33(34.37 \%)$ between $2.1-2.5$ $\mathrm{kg}, 30(31.25 \%)$ between $2.6-3 \mathrm{~kg}$ and $9(9.37 \%)$ with weight $>3 \mathrm{~kg}$. Whereas study conducted by Saraladevi et al had 33 cases of which $1(3.03 \%)$ was $<1.5 \mathrm{~kg}, 1$ $(3.03 \%)$ was between $1.6-2 \mathrm{~kg}$, none between $2-2.5 \mathrm{~kg}$, $20(60.60 \%)$ between $2.5-3 \mathrm{~kg}$ and $8(24.24 \%)$ babies with weight $>3 \mathrm{~kg} .{ }^{8}$ Hyperbilirubinemia was observed in $49(51.04 \%)$ babies, out of which $44(45.83 \%)$ belonged to mothers with subclinical hypothyroidism, which was statistically significant ( $\mathrm{p}<0.05$ ); followed by low birth weight babies which were $55(57.29 \%)$, out of which 48 $(50 \%)$ babies were of mother with subclinical hypothyroidism $(\mathrm{p}<0.05)$. Joshi et al and Saraladevi et al had observed similar findings with respect to neonatal outcomes, but Ajmani et al and Nazarpour S et al didn't report hyperbilirubinemia as a major occurrence. ${ }^{7-9,11}$

\section{CONCLUSION}

In conclusion, it can be deducted that thyroid disorders are more commonly associated with maternal and fetal complications. It is recommended that thyroid profile be considered as universal screening method in early pregnancy to diagnose and start treatment early.

Funding: No funding sources

Conflict of interest: None declared

Ethical approval: The study was approved by the Institutional Ethics Committee

\section{REFERENCES}

1. Eastman CJ. Screening for thyroid disease and iodine deficiency. Pathol. 2012;44(2):153-9.

2. Glinoer D, Nayer PD, Bourdoux P, Lemone M, Robyn $\mathrm{C}$, Steirteghem AV, et al. Regulation of maternal thyroid during pregnancy. The $\mathrm{J}$ Clin Endocrinol Metabol. 1990;71(2):276-87.

3. Khandakar MA, Ali MS, Kahtun M. Thyroid status of normal pregnant women in Dhaka City. Mymensingh Med J. 2002;11(1):1-5.

4. Biondi B, Cooper DS. The clinical significance of subclinical thyroid dysfunction. Endocrine Rev. 2007;29(1):76-131.

5. Sahu MT, Das V, Mittal S, Agarwal A, Sahu M. Overt and subclinical thyroid dysfunction among Indian pregnant women and its effect on maternal and fetal outcome. Arch Gynecol Obstetrics. 2010 Feb $1 ; 281(2): 215$.

6. Okosieme OE, Lazarus JH. Thyroid dysfunction in pregnancy: optimizing fetal and maternal outcomes. Expert Review Endocrinol Metabol. 2010;5(4):521-9.

7. Joshi D, Dewan R, Bharti R, Thariani K, Sablok A, Sharma M, et al. Feto-maternal outcome using new screening criteria of serum TSH for diagnosing hypothyroidism in pregnancy. $\mathrm{J}$ Clin Diag Res. 2015;9(4):QC01.

8. Saraladevi R, Nirmala Kumari T, Shreen B, Usha Rani V. Prevalence of thyroid disorder in pregnancy and pregnancy outcome. IAIM. 2016;3(3):1-1.

9. Ajmani SN, Aggarwal D, Bhatia P, Sharma M, Sarabhai V, Paul M. Prevalence of overt and subclinical thyroid dysfunction among pregnant women and its effect on maternal and fetal outcome. J Obstet Gynecol India. 2014;64(2):105-10.

10. Meena DS, Bhati I, Bora S, Meena S. Study of thyroid dysfunction in pregnancy. Int J Curr Microbiol App Sci. 2015;4(9):91-7.

11. Nazarpour S, Tehrani FR, Simbar M, Azizi F. Thyroid dysfunction and pregnancy outcomes. Iran J Reprod Med. 2015;13(7):387.

12. Allan WC, Haddow JE, Palomaki GE, Williams JR, Mitchell ML, Hermos RJ, et al. Maternal thyroid deficiency and pregnancy complications: implications for population screening. J Med Scree. 2000;7(3):12730.

Cite this article as: Gedam S, Bhushan B. Study of implications of thyroid status over feto-maternal outcomes in pregnancy. Int J Reprod Contracept Obstet Gynecol 2020;9:1946-9. 